\title{
Uma história social da memória da ditadura: o lugar da História Oral na investigação do regime militar
}

\author{
Samuel Silva Rodrigues de Oliveira*
}

DELlAMORE, Carolina, AMATO, Gabriel, BATISTA, Natália (Org.). A ditadura aconteceu aqui - a História Oral e as memórias do regime militar brasileiro. São Paulo: Letra \& Voz, 2017.

O livro A ditadura aconteceu aqui - a História Oral e as memórias do regime militar brasileiro (2017) é uma coletânea de artigos organizada por Carolina Dellamore, Gabriel Amato e Natália Batista. Os organizadores são pesquisadores com doutorados vinculados ao Programa de Pós-Graduação em História na Universidade Federal de Minas Gerais (PPGH-UFMG) e membros do Núcleo de História Oral da Faculdade de Filosofia e Ciências Humanas da mesma universidade (FAFICH-UFMG), coordenados pelos professores Rodrigo Patto Sá Motta e Miriam Hermeto. O grupo se concentra em pesquisas que têm como mote a história do estado de Minas Gerais, do tempo presente e do regime civil-militar brasileiro.

A obra foi lançada no XII Encontro Regional Sudeste de História Oral, ocorrido na UFMG entre 26 a 28 de setembro de 2017. Alguns conferencistas convidados para o evento escreveram capítulos, sendo a maioria dos pesquisadores que publicaram suas reflexóes no livro ligados à instituiçóes universitárias de Minas Gerais, São Paulo e Rio de Janeiro que encontram representação na seção sudeste da Associação Brasileira de História Oral (ABHO). A História Oral aparece em

* Pós-doutor em História pela Universidade Federal Fluminense (UFF), doutor em História, Política e Bens Culturais pelo Centro de Pesquisa e Documentação de História Contemporânea do Brasil (CPDOC-FGV), é professor e pesquisador no ensino integrado e no Programa de Pós-Graduação em Relaçóes Étnico-Raciais do Centro Federal de Educação Tecnológica Celso Suckow da Fonseca (PPRER/CEFET-RJ). E-mail: samu_oliveira@yahoo.com.br. 
sua face múltipla: praticada a partir de inflexóes teóricas e metodológicas diversas e tendo como eixo de preocupação a relação entre a memória social e a História.

A relação entre a memória social e a ditadura é o tema recorrente nas pesquisas do livro. Ao prefacia-lo, Marcos Napolitano salientou a complexidade dessa relação uma vez que "a própria longevidade do regime" permitiu, "a sedimentação de muitas memórias daquela experiência histórica ainda durante sua vigência política, fundindo experiências matrizes em torno do golpe e dos 'anos de chumbo' e narrativas memorialísticas mais ou menos estáveis" (p. 9).

Antes da História Oral se institucionalizar em associaçóes, núcleos de pesquisa e documentação e nas pesquisas acadêmicas, houve a elaboração de um conjunto de testemunhos que sedimentaram uma memória social sobre a ditadura. A realização de entrevistas na investigação de diversos aspectos da sociedade, a formação dos acervos de História Oral abordando o regime autoritário e a historiografia do período foram direta e indiretamente influenciados por essa memória social. A presença viva das testemunhas do regime civil-militar, as lutas da direita e a da esquerda pela posse da representaçáo do passado recente, e as formas de acomodação e resistência dos diferentes agentes sociais na ditadura e na redemocratização do país configuram um jogo de força que influiu na pesquisa e escrita da história da ditadura civil-militar.

Os coordenadores do livro, mostram como a metodologia da História Oral é importante para a renovação da historiografia da ditadura. Dividiram a coletânea de artigos em duas partes: "A polifonia das memórias da ditadura" e "A História Oral, os espaços de escuta e a construção de acervos". No conjunto da obra, encontra-se uma história social da memória do regime autoritário a partir de diferentes posiçóes sociais: militares, trabalhadores, estudantes, habitantes de cidades do interior na Amazônia, artistas, guerrilheiros, integrantes do movimento negro, travestis e "gays", índios, presos políticos, familiares de desaparecidos políticos, militantes, mulheres de esquerda e anarquistas.

No conjunto dos artigos reunidos na primeira parte do livro, as esquerdas são pensadas em sua pluralidade, desconstruindo a imagem de uma "união" ou homogeneidade nas açóes contra a ditadura. Dialogam com tal problema os artigos: "Resistência cultural à ditadura: Memórias e narrativas na construção da trajetória do Grupo Opinião" de Natália Batista, "Legítimos propagadores do racismo negro?' O movimento negro contemporâneo e a luta contra o racismo na ditadura civil-militar no Brasil" de Amilcar Araújo Pereira e Agenor Brito dos Santos Neto, "História e memória das mulheres na Ação Popular (AP)" de Débora Raiza Rocha, "As relaçóes entre a política indigenista e a repressão a povos indígenas em Minas Gerais durante a ditadura: Notas sobre a experiência Xabriabá" de Juliana Ventura, "Se correr o bicho pega... Repressão policial a gays e travestis nos anos 1970 em Belo Horizonte" de Luiz Morando e "Sementes em terreno pedregoso: O anarquismo na ditadura militar brasileira" (1964-1965)” de Rafael Viana da Silva.

Nessa primeira parte do livro, ainda se destaca a reflexão sobre a ambivalência dos grupos sociais em relação ao regime. Os autores problematizam 
as representaçóes maniqueístas e unívocas da ditadura, apresentando os esforços de construção social do regime autoritário numa relação complexa de legitimidade e resistência a partir de diferentes posiçóes sociais e políticas. Os artigos que colocam tal questão em primeiro plano são: "Vozes da Transamazônica: Memória e historia dos anos Médici nos recônditos da Amazônia" de César Martins de Souza e Janaína Cordeiro, "Conquistando coraçóes e mentes: Açôes cívico-sociais no contexto da repressão à guerrilha do Caparaó" de Plínio Ferreira Guimarães, "(Re)compondo memórias de um Operário Padrão durante a ditadura militar" de Carolina Dellamore, e "Memórias de rondonista: Lembrando outras maneiras de ser estudante durante a ditadura militar" de Gabriel Amato.

$\mathrm{Na}$ segunda parte do livro, intitulada "A História Oral, os espaços de escuta e a construção de acervos", são apresentados alguns projetos de História Oral e centros de memória. Os pesquisadores observam o desafio de construir acervos em conjunturas de disputa de memórias e em diferentes conjunturas da justiça de transição" no Brasil. No artigo "A memória militar: Revisitando uma pesquisa”, Celso Castro enfoca a maneira como as diferentes conjunturas políticas da democracia brasileira, dos anos 1990 aos anos 2000, influenciaram no projeto de História Oral dos militares do Centro de Pesquisa e Documentação de História Contemporânea do Brasil (CPDOC-FGV). Nos artigos "Memórias do cárcere da ditadura: O projeto de História Oral dos presos políticos no Brasil" de Janaína de Almeida Teles e "Os familiares de desaparecidos políticos do Araguaia e a CNV: A luta por verdade e justiça" de Deusa Maria de Sousa e Maria Cecília de Oliveira Adão, são apresentadas a forma como a História Oral dos presos políticos e de familiares desaparecidos é atravessada por diferentes conjunturas da luta pelo reconhecimento dos direitos humanos e dos crimes praticados pelo Estado autoritário.

$A$ "Ditadura aconteceu aqui" foi publicado numa conjuntura que tornou desafiador realizar pesquisas de História Oral sobre o regime militar. Como salientaram Carolina Dellamore, Gabriel Amato e Natália Batista, "o senso comum, postulante da ideia de que 'o brasileiro não tem memória', parece estar sendo desafiado" por uma parte expressiva dos brasileiros que "lançam mão das lembranças de políticas desenvolvimentistas, do patriotismo e do anticomunismo para positivar um regime que censurou a imprensa e as artes, que adotou a tortura como política de estado e que prendeu, exilou, 'desapareceu' e matou por motivos políticos” (p. 17). Num contexto de ascensão das direitas e de revisóes da história do regime autoritário brasileiro, a leitura do livro é instigante e necessária, pois permite refletir sobre os limites e as potencialidades da metodologia de História Oral na atualidade.

1 Medidas jurídicas e políticas para reconhecer os crimes contra os direitos humanos praticados na ditadura civil-militar brasileira e reparar a sociedade e os grupos atingidos pela violência de Estado. 
Recebido em 12/06/19

Aprovado em 09/10/19 